\title{
EVALUATION OF QUALITY OF LIFE INDICATORS IN NSTEMI PATIENTS DEPENDING ON PLASMA LEVEL ST2, NATURE OF CORONARY ARTERIES LESION AND OTHER CLINICAL CHARACTERISTICS
}

\begin{abstract}
Introduction. The prevalence of myocardial infarction and its leading role in the structure of overall and cardiovascular mortality encourages the search for predictors of adverse disease and the search for optimal means to prevent adverse events and improve the quality of life of this category of patients.

The aim of the study - to evaluate quality of life in NSTEMI patients based on plasma ST2 levels, the nature of coronary artery disease, and other clinical characteristics.

Research Methods. The study involved 200 patients with NSTEMI aged 38 to 80 years. All patients were examined according to the current treatment protocol for patients with acute myocardial infarction without ST segment elevation, plasma ST2 levels were determined and quality of life was assessed using the MIDAS-35 questionnaire.

Results and Discussion. Spearman's rank correlation showed that the level of physical activity (the first subscale of MIDAS-35) of patients with NSTEMI is directly correlated with the presence of frequent ventricular extrasystoles and paroxysms of ventricular tachycardia recorded during ECG monitoring on day 1 of NSTEMI, the severity of coronary artery lesions and plasma ST2 levels determined on the 1st day of hospitalization. Similar patterns are found in subscales 2, 4, 5. Subscale 6 revealed the presence of a correlation only with the presence of frequent ventricular tachycardia. Subscales 3 and 7 did not show correlations with the studied parameters.

Conclusions. Elevated ST2 levels, hemodynamically significant coronary artery lesions and the presence of acute arrhythmias in the early period of NSTEMI have been found to significantly affect quality of life as determined by the MIDAS-35 questionnaire. The impact on remodeling processes and the strategy of early invasive treatment in patients with NSTEMI will not only reduce the likelihood of complications, but also improve the quality of life of this category of patients.
\end{abstract}

KEY WORDS: NSTEMI; quality of life; ST2; coronary arteries.

INTRODUCTION. The prevalence of myocardial infarction and the risk of adverse and fatal events in the early period lead to the search for a variety of non-invasive biomarkers, which have the ability to predict the course of the disease. One of the factors that has been actively studied recently is the growth stimulating factor expressed by the 2 (ST2) gene [1]. ST2 is a member of the family of interleukin-1 (IL-1) receptors with isoforms associated with membrane ST2 (ST2L) and soluble (SST2) forms. IL-33/ST2L signaling protects the myocardium from hypertrophy and fibrosis of the heart after pressure overload [2, 3]. Soluble ST2 acts as a bait receptor for IL-33 and prevents IL-33/ST2L interactions and subsequent cardioprotective cascade events.

The aim of the study - to evaluate quality of life in NSTEMI patients based on plasma ST2 levels, the nature of coronary artery disease, and other clinical characteristics.

(c) V. I. Maslovskyi, 2021.
RESEARCH METHODS. We conducted a comprehensive study of 200 patients with acute myocardial infarction without ST-segment elevation (NSTEMI) aged 38-80 (mean (62.0 \pm 0.71$)$, median -62 and interquartile range -55 and 70 ) years, who were hospitalized in the Municipal Non-Profit Enterprise "Vinnytsia Regional Clinical Medical and Diagnostic Center for Cardiovascular Pathology" with urgent indications.

The criteria for including patients in the study were:

1. Verified NSTEMI, first diagnosed;

2. Age up to 80 years;

3. The absence of contraindications to percutaneous coronary interventions and the use of the main groups of pharmacological agents included in the basic therapy of NSTEMI;

4. Informed consent of the patient to participate in the study.

The criteria for exclusion from the study were:

1. STEMI, transferred in the past and recurrent acute myocardial infarction; 
2. Age of patients 80 years and older;

3. The presence of sinoatrial or atrioventricular block degree ii-iii, implanted or the need for implantation of an artificial pacemaker;

4. Chronic heart failure nyha-iii, iv before the incident of acute myocardial infarction;

5. Diseases of the respiratory system, kidneys and liver, which were accompanied by signs of pulmonary, renal and hepatic failure; anemic conditions with a hemoglobin level below $110 \mathrm{~g} / \mathrm{l}$;

6 . The presence of rheumatic and congenital heart defects, idiopathic and inflammatory myocardial lesions;

7. Malignancies, severe neuropsychiatric disorders, alcohol abuse;

8. The presence of contraindications to percutaneous coronary interventions and the use of the main groups of pharmacological agents included in the basic therapy nstemi;

9. Reluctance and refusal of the patient to participate in the study.

all patients were examined according to the NSTEMI protocol [4]. Determining of the plasma ST2 levels was performed by enzyme-linked immunosorbent assay in all patients on the first day of hospitalization before hospital coronary angiography [5]. Assessment of quality of life was performed on day 5-7 of the patient's stay in the clinic using the MIDAS-35 questionnaire [6].

RESULTS AND DISCUSSION. The method of variation statistics determined that in the examined sample of NSTEMI patients $(n=200)$ the average ST2 level was $49.60 \mathrm{ng} / \mathrm{ml}$ at the minimum and maximum values of 10.88 and $233.94 \mathrm{ng} / \mathrm{ml}$, respectively, and the standard deviation of the mean value $\sigma$ ) -44.85 . The median was 35.49 and the interquartile range (upper and lower 75 percent) was 24.23 and $55.60 \mathrm{ng} / \mathrm{ml}$, respectively. Thus, the obtained data showed that in $75 \%$ of the examined NSTEMI patients the level of ST2 in plasma ranged from 24.23 to $55.60 \mathrm{ng} / \mathrm{ml}$.

Using the median of the indicators determined for the total sample of patients NSTEMI $(n=200)$, two levels of ST 2 were identified: $1^{\text {st }}$ - relatively low, which corresponded to the value of the indicator in the sample $<$ Mediana and $2^{\text {nd }}$ - relatively high $\geq$ Mediana. It was found that in NSTEMI patients the calculated and rounded median values for ST2 were $36 \mathrm{ng} / \mathrm{ml}$. The values of indicators as $<36$ were regarded as a relatively low level (BP) and $\geq 36$ - as a relatively high level of indicators $(R H)$.

To assess the severity of damage to individual main arteries, we calculated a conditional score of coronary arteries (CA), where 0 points - the absence of any a/plaques in the CA (intact artery), 1 point - the presence of atherosclerotic stenosis up to $50 \%, 2$ points - from 50 to $90 \%$ of the CA lumen and 3 points - CA occlusion (atherosclerotic stenosis $>90 \%$ ) [7]. In addition, the total conditional CA lesion score was additionally calculated as the sum of the right coronary artery (RCA), left anterior descending artery (LAD), and left circumflex artery (LCX) lesion scores. According to the obtained data, it was observed that the mean conditional score of RCA lesions was $(0.74 \pm 0.08), L A D-(2.03 \pm 0.10)$ and LCX $-(0.89 \pm 0.09)$, respectively. The total conditional CA lesion score was (3.66 \pm 0.17$)$. It was noted that among the examined cohort of NSTEMI patients the most severe CAlesion was determined in the LAD, which was characterized by a significant increase in the incidence of registered hemodynamically significant stenosis (HSS) $(64.7 \%$ vs. $25.6 \%$ for RCA and $31.4 \%$ for LCx, $p<0.0001$ and $p<0.0001$, respectively) and a higher conditional CA lesion score (2.03 vs. 0.74 for RCA and 0.89 points for LCX, $p<0.0001$ and $p<0.0001$, respectively).

Overall Quality of Life Assessment (QL) according to the valid MIDAS-35 score $\subset$ Oxford University Innovation Limited, 2002. All rights reserved [6], which was conducted on day 5-7 MI, in the general group of NSTEMI patients examined, ranged from 13.2 to 74.4 and averaged 38.6 (mathematical error of the average - 1.12), median - 37.9 and interquartile variation -24.4 and 48.6 , respectively. Therefore, based on the variation statistics, it should be assumed that $50 \%$ of NSTEMI patients included in the study had a total QL score of MIDAS-35 in the range of $24.4-48.6$, while $25 \%-<24.4$ and another $25 \%$ of patients $->48.6$ points. A significant variation in QL levels in the examined patients is noteworthy.

We conducted a detailed analysis of the relationship of all components of the MIDAS-35 score, with different clinical, instrumental and laboratory parameters in the general group of patients with NSTEMI using Spearman's rank correlation (Table).

It was found that the level of physical activity of NSTEMI patients showed a direct correlation with the presence of frequent ventricular extrasystoles (VE) $(R=0.20, p=0.009)$ and paroxysms of ventricular tachycardia (VT) $(R=0.23, p=0.002)$, recorded during ECG monitoring on the 1st day of $\mathrm{MI}$, the severity of anatomical lesions of LCX, determined by coronary angiography $(R=0.21, p=0.006)$ and the level of $\mathrm{ST} 2$ in plasma in $\mathrm{ng} / \mathrm{ml}(\mathrm{R}=0.21$, $p=0.006$ ), determined on the 1st day of hospitalisation.

Similar patterns are found in subscales 2, 4, 5 . Subscale 6 revealed the presence of a correlation only with the presence of frequent VT. Subscales 3 and 7 did not show correlations with the studied parameters. 
Table - Spearman's rank correlation of MIDAS-35 score components in IMbelST patients with different clinical, instrumental and biochemical parameters

\begin{tabular}{|c|c|c|}
\hline MIDAS-35 subscale scores & Spearman R & P-value \\
\hline \multicolumn{3}{|l|}{ 1. Physical activity } \\
\hline The presence of frequent VE on the 1st day of MI (yes -1, no -0$)$ & 0.20 & 0.009 \\
\hline The presence of paroxysms of VT on the 1st day of MI (yes -1, no -0$)$ & 0.23 & 0.002 \\
\hline The severity of LCx damage & 0.21 & 0.006 \\
\hline ST2 level, $\mathrm{ng} / \mathrm{ml}$ & 0.21 & 0.005 \\
\hline \multicolumn{3}{|l|}{ 2. Insecurity } \\
\hline The presence of frequent VE on the 1st day of MI (yes -1, no -0$)$ & 0.21 & 0.007 \\
\hline The presence of paroxysms of VT on the 1st day of MI (yes -1, no -0$)$ & 0.30 & $<0.0001$ \\
\hline ST2 level, $\mathrm{ng} / \mathrm{ml}$ & 0.24 & 0.001 \\
\hline \multicolumn{3}{|l|}{ 3. Emotional reaction } \\
\hline \multicolumn{3}{|l|}{ No correlations were found } \\
\hline \multicolumn{3}{|l|}{ 4. Dependency } \\
\hline The presence of frequent VE on the 1st day of $\mathrm{MI}(\mathrm{yes}-1, \mathrm{no}-0)$ & 0.27 & 0.0003 \\
\hline ST2 level, $\mathrm{ng} / \mathrm{ml}$ & 0.20 & 0.008 \\
\hline \multicolumn{3}{|l|}{ 5. Diet } \\
\hline The presence of frequent VE on the 1st day of MI (yes -1, no -0$)$ & 0.29 & 0.0001 \\
\hline The presence of paroxysms of VT on the 1st day of MI (yes -1, no -0$)$ & 0.21 & 0.007 \\
\hline ST2 level, $\mathrm{ng} / \mathrm{ml}$ & 0.23 & 0.002 \\
\hline \multicolumn{3}{|l|}{ 6. Concerns over medication } \\
\hline The presence of frequent VE on the 1st day of MI (yes -1, no -0$)$ & 0.28 & 0.0002 \\
\hline \multicolumn{3}{|l|}{ 7. Side effects } \\
\hline No correlations v & & \\
\hline
\end{tabular}

Using Spearman's rank correlation, we established certain patterns between different clinical and instrumental parameters and quality of life indicators according to MIDAS-35. There are a number of studies that have also studied the quality of life in myocardial infarction, as well as the assessment of treatment regimens for heart attacks $[8,9]$. However, we have for the first time assessed the correlations with both the structural and clinical features of the disease and with the new biomarker ST2, the effect of which on the course of myocardial infarction is currently being actively studied. In addition, our study as a subject of study considered the development of pathological processes in NSTEMI. Understanding these processes in the future will not only predict the course of NSTEMI, but also reduce the likelihood of complications in the early period and improve the quality of life of these patients.

CONCLUSIONS. 1. It was found that elevated ST2 levels, hemodynamically significant lesions of the coronary arteries and the presence of acute arrhythmias in the early period of NSTEMI significantly affect the quality of life indicators determined by the MIDAS-35 score.

2. Impact on remodeling rates and early invasive treatment strategy in patients with NSTEMI will not only reduce the likelihood of complications, but also improve quality of life in this category of patients.

\section{LITERATURE}

1. Prognostic value of serial ST2 measurements in patients with acute heart failure / L. C. van Vark, I. LesmanLeegte, S. J. Baart [et al.] // J. Am. Coll. Cardiol. -2017. 70, Issue 19. - P. 2378-2388. DOI: 10.1016/j.jacc.2017. 09.026 .

2. Head-to-head comparison of 2 myocardial fibrosis biomarkers for long-term heart failure risk stratification / A. Bayes-Genis, M. de Antonio, J. Vila [et al.] // J. Am. Coll. Cardiol. - 2014. - 63, Issue 2. - P. 158-166. DOI: $10.1016 /$ j.jacc.2013.07.087.

3. Villacorta H. Soluble ST2 testing: promising biomarker in the management of heart failure / $\mathrm{H}$. Villacorta, A. S. Maisel // Arq. Bras. Cardiol. -2016. -106, Issue 2. P. 145-152. DOI: 10.5935/abc.20150151.
4. 2020 ESC Guidelines for the management of acute coronary syndromes in patients presenting without persistent ST-segment elevation / J. P. Collet, H. Thiele, E. Barbato [et al.] // Eur. Heart J. - 2021. - 42, Issue 14. P. 1289-1367. DOI: 10.1093/eurheartj/ehaa575.

5. Mueller T. The Presage $₫ S T 2$ Assay: analytical considerations and clinical applications for a highsensitivity assay for measurement of soluble ST2 / T. Mueller, B. Dieplinger // Exp. Rev. Mol. Diagn. -2013. 13, Issue 1. - P. 13-30. DOI: 10.1586/erm.12.128.

6. Application of quality nursing care for interventional therapy in myocardial infarction for improving the quality of life of patients / C. Guo, S. Feng, Y. Chen, M. Liu // Int. J. Clin. Exp. Med. - 2020. - 13, Issue 4. - P. 2565-2572. 
7. Ivanov V. Characteristics of anatomic injury of coronary arteries in patients with acute myocardial infarction without ST elevation depending on plasma level of gene 2 growth stimulating factor and risk of adverse events / V. Ivanov, I. Mezhievska, V. Maslovskyi // Acta Medica Leopoliensia. - 2020. - 26, Issue 1. - P. 20-25.

8. Thompson D. R. Mokken scaling of the Myocardial Infarction Dimensional Assessment Scale (MIDAS) /

\section{REFERENCES}

1. van Vark, L.C., Lesman-Leegte, I., Baart, S.J., Postmus, D., Pinto, Y.M., Orsel, J.G., ..., \& Akkerhuis, K.M. (2017). Prognostic value of serial ST2 measurements in patients with acute heart failure. J. Am. Coll. Cardiol., 70 (19), 2378-2388. DOI: 10.1016/j.jacc.2017. 09.026 .

2. Bayes-Genis, A., de Antonio, M., Vila, J., Peñafiel, J., Galán, A., Barallat, J., ..., \& Lupón, J. (2014). Head-to-head comparison of 2 myocardial fibrosis biomarkers for long-term heart failure risk stratification. J. Am. Coll. Cardiol., 63 (2), 158-166. DOI: 10.1016/j. jacc.2013.07.087.

3. Villacorta, H., \& Maisel, A.S. (2016). Soluble ST2 testing: promising biomarker in the management of heart failure. Arq. Bras. Cardiol., 106 (2), 145-152. DOI: 10.5935/ abc. 20150151.

4. Collet, J.P., Thiele, H., Barbato, E., Barthélémy, O., Bauersachs, J., Bhatt, D.L., ..., \& Siontis, G.C.M. (2021). 2020 ESC Guidelines for the management of acute coronary syndromes in patients presenting without persistent ST-segment elevation. Eur. Heart J., 42 (14), 1289-1367. DOI: 10.1093/eurheartj/ehaa575.

5. Mueller, T., \& Dieplinger, B. (2013). The Presage ${ }^{\circledR S T} 2$ Assay: analytical considerations and cli-
D. R. Thompson, R. Watson // J. Eval. Clin. Pract. 2011. - 17, Issue 1. - P. 156-159. DOI: 10.1111/j.13652753.2010.01415.x.

9. Development and validation of a short measure of health status for individuals with acute myocardial infarction: the myocardial infarction dimensional assessment scale (MIDAS) / D. R. Thompson, C. Jenkinson, A. Roebuck [et al.] // Qual. Life Res. - 2002. - 11, Issue 6. - P. 535-543. DOI: 10.1023/a:1016354516168.

nical applications for a high-sensitivity assay for measurement of soluble ST2. Exp. Rev. Mol. Diagn., 13 (1), 13-30. DOI: 10.1586/erm.12.128.

6. Guo, C., Feng, S., Chen, Y., \& Liu, M. (2020). Application of quality nursing care for interventional therapy in myocardial infarction for improving the quality of life of patients. Int. J. Clin. Exp. Med., 13 (4), 25652572.

7. Ivanov, V., Mezhievska, I., \& Maslovskyi, V. (2020). Characteristics of anatomic injury of coronary arteries in patients with acute myocardial infarction without ST elevation depending on plasma level of gene 2 growth stimulating factor and risk of adverse events. Acta Medica Leopoliensia, 26 (1), 20-25.

8. Thompson, D.R., \& Watson, R. (2011). Mokken scaling of the Myocardial Infarction Dimensional Assessment Scale (MIDAS). J. Eval. Clin. Pract., 17 (1), 156-159. DOI: 10.1111/j.1365-2753.2010.01415.x.

9. Thompson, D.R., Jenkinson, C., Roebuck, A., Lewin, R.J., Boyle, R.M., \& Chandola, T. (2002). Development and validation of a short measure of health status for individuals with acute myocardial infarction: the myocardial infarction dimensional assessment scale (MIDAS). Qual. Life Res., 11 (6), 535-543. DOI: 10.1023/ a:1016354516168.

\section{ОЦІНКА ПОКАЗНИКІВ ЯКОСТІ ЖИТТЯ У ПАЦІЄНТІВ 3 NSTЕМІ ЗАЛЕЖНО ВІД ПЛАЗМОВОГО РІВНЯ SТ2, ХАРАКТЕРУ УРАЖЕННЯ КОРОНАРНИХ АРТЕРІЙ ТА ІНШИХ КЛІНІЧНИХ ХАРАКТЕРИСТИК}

\section{Резюме}

Вступ. Поширеність інфаркту міокарда і його провідна роль у структурі загальної та серцево-судинної смертності спонукають до пошуку предикторів несприятливого перебігу захворювання і пошуку оптимальних засобів для профрілактики несприятливих подій та покращення якості життя цієї категорії пацієнтів.

Mета дослідження - оцінити показники якості життя у пацієнтів з NSTEMI залежно від характеру анатомічного ураження коронарних артерій, рівня ST2 у плазмі та інших клінічних характеристик. 
Meтоди дослідження. У дослідженні взяли участь 200 пацієнтів з NSTEMI віком від 38 до 80 років. Усіх їх обстежено відповідно до діючого протоколу лікування пацієнтів із гострим інорарктом міокарда без елевації сегмента ST, визначено плазмовий рівень ST2 та проведено оцінку якості життя за опитувачем MIDAS-35.

Результати й обговорення. За допомогою кореляційного рангового аналізу Спірмена встановлено, що рівень фрізичної активності (першої субшкали MIDAS-35) хворих на NSTEMI проявляє пряму кореляцію з наявністю частих шлуночкових екстрасистол та пароксизмів шлуночкової тахікардії, зареєстрованих під час ЕКГ-моніторингу на 1-й день NSTEMI, тяжкістю анатомічного ураження коронарних артерій, визначених за даними коронарографрії та рівнем ST2 у плазмі, встановленим на 1-й день госпіталізації. Подібні закономірності виявили в субшкалах 2, 4, 5. Субшкала 6 виявила кореляцію лише з наявністю частої шлуночкової тахікардії. Субшкали 3 і 7 не виявили кореляції з досліджуваними параметрами.

Висновки. Встановлено, що підвищений рівень ST2, гемодинамічно значущі ураження коронарних артерій та наявність гострих аритмій у ранній період NSTEMI суттєво впливають на показники якості життя, визначені за шкалою MIDAS-35. Вплив на процеси ремоделювання та стратегія раннього інвазивного лікування у пацієнтів з NSTEMI не тільки знизять імовірність розвитку ускладнень, але й покращать якість життя цієї категорії пацієнтів.

КЛЮЧОВІ СЛОВА: NSTEMI; якість життя; ST2; коронарні артерії.

Received 26.11.21

Address for correspondence: V. I. Maslovskyi, Keletska Str. 50b, ap. 127, Vinnytsya, 21021, Ukraine, e-mail: vmaslovskyi@gmail.com. 